7. Фрай Р. Наследие Ирана. Пер. с англ. В.А. Лившица и Е.В. Зеймаля; под ред. и с предисл. М.А. Дандамаева. 2-е изд., испр. и доп. Москва: Восточная литература, 2020. 463 с.

8. Kellens J. Druj-/ Encyclopeadia Iranica, Online Edition, 1996. URL: http://www.iranicaonline.org/articles/druj. Дата звернення: 20.02.2021.

DOI https://doi.org/10.30525/978-9934-26-039-1-46

\title{
ПОРІВНЯЛЬНО-КОНЦЕПТУАЛЬНИЙ АНАЛІЗ ТВОРІВ В. ВУЛФ ТА ДЖ. ДЖОЙСА
}

\author{
Матковська М. В. \\ доиент кафедри англійської мови \\ Кам'янець-Подільського національного університету \\ імені Івана Огієнка \\ м. Кам'янеиь-Подільський, Хмельницька область, Украӥна
}

Вірджинія Вулф (1882-1941), британський романіст, есеїст і критик, сприяла створенню сучасного роману. В іiі роботах часто досліджується концепти часу, пам'яті і внутрішньої свідомості людей.

Джеймс Джойс (1882-1941), представник ірландської модерністської і постмодерністської прози, виступив як засновник нової поетики, нових способів письма, в яких форма по суті репрезентує зміст, кодуючи в собі моральні, естетичні, психологічні і інші вимірювання.

Концепти, які ми досліджуємо в творах В. Вулф та Дж. Джойса, виражають певні емоції й наміри. Існують шість емоцій, які універсально свіввідносяться 3 мімікою обличчя: щастя, печаль, гнів, страх, здивування та інтерес. Різні похідні слова, подібно до англійського 'досада', 'дратування', показують слабкіші або сильніші ефекти прототипу, в даному випадку, від прототипічного 'гнів'. Вони не завжди володіють прямими еквівалентами в іншій мові ('досада' - в польській або російській мовах розуміється як конструктивний термін, що об'єднує два різні прототипи: 'гнів' і ‘печаль').

Наша мета - визначити специфіку аналізу порівняльно-концептуального простору в творах В. Вулф та Дж. Джойса.

Конецпт намірів походить онтогенетично від примітивного концепту хотіти. Обидва вони передують таким концептам як иџілі й плани, які можна вивести шляхом умовиводу як орієнтовані концепти. 
Окрім концептуальних принципів називання, що дають початок універсальним концептам і які здебільшого відповідальні за те, що ми називаємо основною частиною лексичного значення, є також чинники іншої природи, які мають обмежену або диференційовану функцію щодо універсальних принципів. Ці соціокультурні, а також характерні (емпіричні) фактори, тісно пов'язані з різними системами переконань (основ фрейму), мають сильний вплив на категоризацію аспекту реальності і можливих стосунків [3, p. 215]. Класифікація універсальних понять, представлених у списку, може розглядатися як вмотивована еволюційними чинниками.

Концепт простору, який знаходиться нагорі ієрархії, є центральним виміром людської пізнавальної системи. Необхідні деякі вроджені схильності для розвитку чи набуття відповідного концепту; це підтверджене тим фактом, що сліпі від народження особи розвивають концепт простору як інші люди, навіть тоді, коли цей розвиток істотно затримується. Простір діє як параметр, який залучений до концептуально/семантичної структури універсальних понять, наприклад: час - концептуальне представлення часу є просторове (лінійне) лексичне значення, що позначає час як повторювальний проміжок просторових відображень; зображення/основа виступають як прототипічно просторові відносини, розширені до інших видів переднього плану і фону; его - перспективне представлення, поєднане з розвитком концепції piч/особа. Просторово прототипічна конфігурація включає егоцентризм, що може бути розширений в двох напрямах: - егоцентризм, перенесений на інші пізнавальні/когнітивні області, напр. 'хотіти/мати намір' та егоцентризм, направлений на спікер-центризм і на центризм інших користувачів мови $[5$, p. 21].

У цьому випадку, як зауважує А. Вежбицька, те, що $є$ первинним в просторовому сприйнятті і концепції і те, що здається основою для лінгвістичного просторового визначення, не $є$ абсолютним, а суб'єктивним простором, який сприймається індивідуально, окремим представником категорії homo sapiens, або індивідуумом, членом соціокультурної спільноти [6, p. 402].

Значимість зображення/основи вимагає спеціальної уваги. Воно походить від фізичної здатності відділяти об'єкти від їх оточення і від їх перцептивної особливості, i тоді поширюється на когнітивну i лінгвістичну площини. Те, що може вважатися таким же епізодом у зовнішньому світі, може бути забарвлене лінгвістично або умовно розмовним співтовариством, або суб'єктивно - індивідом, як вираз того, 
що різні аспекти реальності можуть бути розміщеними у фокусі лінгвістичного виразу тієї реальності [3, p. 121].

Тому лінгвістична форма створює параметри когнітивного значення, що дає в результаті лінгвістичне значення, яке з (морфо-синтаксичної і фонологічної) потреби виражає інтерпретацію світу, який сприймається. Будь-який приклад одиничного, лінгвістично вираженого значення діє так, але особливо яскравими прикладами цього є концепти кількість множина як однина, так і множина в різних мовах [6, p. 313].

Інші концепти, запропоновані вище, можуть розглядатися як комплексні, а не як структурно прості конструкції, наприклад: підбір включає зображення/основа, ціле/частина і т.п.; стабільність/зміна включає в себе час, річ/особу. 3 іншого боку, комбінація концептів може вести до утворення інших понять: причина включає час (послідовність), висновок(умовивід) і т.П.; дія вимагає особи, зміни, наміру тощо.

Планування, 3 іншого боку, окрім побудованої гіпотези дії, передбачає, в першу чергу, бажання і намір. До того ж, включає в себе цілий ряд розумових здібностей (знання), які могли б дозволити підрахунок можливих досягнень і втрати визначеної мети. Розумові здібності роблять можливим підрахунок особливостей, не безпосередньо сприйнятих, як розглядалося раніше в світлі відношення 'частина-ціле', а як умова, результат дії правил, які ведуть до утворення мовноспецифічного значення [1, с. 204].

Концепти виконують ряд функцій, що їх характеризують. Концептуальний аналіз дає змогу ототожнити ці функції. Різні мови відображають концепти і відносини на більш специфічних схемах та ієрархіях лінгвістично виражальних значень. Підієрархії, не показані в списку основних універсальних концептів, лежать в основі кожного 3 примітивних понять й експонуватимуть конфігурації, що змінюються. Вони представляють структуровані концептуальні області, які відображаються в різних мовах. Із-за цієї причини їх організація вмотивована також певними культурно-специфічними та інтерактивними параметрами.

Деякі з цих параметрів, в свою чергу, знайдені в англійській мові, також в польській і російській мовах. Варто зазначити, що англійська мова має 'вищу' ієрархічну структуру, об'єднуючи (у полі і периферіі) концепти в уоn (туди) і yondez (ось той) (зараз застарілі) [6, р. 213].

Концептуальний аналіз тексту дає підстави стверджувати, що всі основні і похідні концепти можуть знаходитися в термінах простору, які містять в собі області значень та прагматично організовані за допомогою (слабких) імплікаційних зв'язків і гіпонімічних відносин. Іерархічні 
структури, організовані навколо концепту, розглядаються як концептуальні або когнітивні області. Когнітивні області включають в себе конфігурації, що відповідають одиничному лексичному значенню в розмовній мові або комплексному (перефразованому) лексичному значенню, або нульовому лексичному значенню (лексична лакуна) у мові. До того ж особливо доречно є специфічні значення, пов'язані $з$ концептуальними сферами, доведені як через лінгвістичні системи, так i через певну культурно-специфічну поведінку [2, с. 98].

Твори Дж. Джойса та В. Вулф відзначаються глибоким інтересом до концептів часу, пам'яті, свідомості людини, глибини сприйняття нею зовнішнього світу. Варто зазначити, що вищезгадані автори приділяють дуже велику увагу опису думок героїв, їх почуттів, роздумів, умовиводів. Завдяки стилю письма «потік свідомості» - читач має надзвичайну нагоду зазирнути у внутрішній світ героїв романів Дж. Джойса «Портрет Митця Замолоду» та В. Вулф «На Маяк», представлений мовою художнього оригіналу, наприклад: «What does it mean then, what can it all mean? Lily Briscoe asked herself, wondering whether, since she had been left alone, it behaved her to go to the kitchen to fetch another cup of coffee or wait here. What does it mean? ... Nothing, nothing - nothing that she could express at all» [7, p. 213].

У романах наявні також і описи, що включають категорії таких обставин, як місце, спосіб дії, час і т.д. Наприклад, цитуємо мовою оригіналу:»Stephen was once again seated beside his father in the corner of a railway carriage at Kingsbridge. He was travelling with his father by the night mail to Cork. As the train steamed out ... he recalled his childish wonder of years before ...» [4, p. 76].

Отже, психологічні моделі розглядаються як структурні об'єкти, які виникають у процесі розуміння і оцінки подій, що трапляються в соціумі. Вони відображають знання, установки і переконання мовця. Аналіз текстів дозволяє нам зрозуміти соціальну обумовленість природної мови, розкрити особливості упереджень і описати когнітивні стратегії, якими користуються автори.

\section{Література:}

1. Ларина Т.В. Категория вежливости в английской и русской коммуникативных культурах. М.: РУДН, 2004. 345 с.

2. Сахно С. Л. «Свое - Чужое» в концептуальных структурах Логический анализ языка. Культурные кониептыл. Москва : Наука, 1991. C. $95-101$. 
3. Brown P., Levinson S. Politeness: Some Universals in Language Usage. Cambridge : Cambridge University Press, 1987. 345 p.

4. Joyce James A Portrait of the Artist as a Young Man. London : Penguin Popular Classics, 1996. 288 p.

5. Wierzbicka A. Understanding cultures through their key words: English, Russian, Polish, German, and Japanese. New York, Oxford : Oxford University Press, 1997. 328 p.

6. Wierzbicka A. Cross-cultural Pragmatics: The Semantics of Human interaction. Berlin/NY : Walter de Gruyter, 2003. 502 p.

7. Woolf V. To the Lighthouse. London : Penguin Popular Classics, 1996. $306 \mathrm{p}$.

DOI https://doi.org/10.30525/978-9934-26-039-1-47

\title{
ТАКТИКИ РЕАЛІЗАЦІЇ ПРЕВЕНТИВНОЇ \\ СТРАТЕГІЇ ВИБОРУ ПАРТНЕРА (НА МАТЕРІАЛІ НІМЕЦЬКОМОВНОГО ВІРТУАЛЬНОГО ДИСКУРСУ)
}

\author{
Пасик Л. А. \\ кандидат філологічних наук, \\ доиент кафедри німеиької філології
}

Волинського національного університету імені Лесі Украӥнки

Рись Л. Ф.

кандидат філологічних наук, доцент, доиент кафедри німецької філології

Волинського національного університету імені Лесі Украӥнки м. Луиьк, Украӥна

Терміни «стратегія» і «тактика» ще й зараз не мають однозначного трактування з точки зору лінгвістів. Дехто вважає «стратегію» ширшим поняттям, як «тактика», а інші їх цілком ототожнюють.

Мета наукової розвідки полягає у 3'ясуванні тактик реалізації превентивної стратегії вибору партнера в оголошеннях про знайомство та в анкетах на сайтах знайомств. Для досягнення поставленої мети необхідно виконати наступні завдання: 1) розглянути сутність превентивної стратегії самопрезентації; 2) виявити тактики реалізації цієї стратегії та проаналізувати мовні засоби їх вираження. 